JAMP: Jurnal Adminitrasi dan Manajemen Pendidikan

Volume 3 Nomor 1 Maret 2020, Hal : 61-71

Tersedia Online di http://journal2.um.ac.id/index.php/jamp/

ISSN 2615-8574 (online)

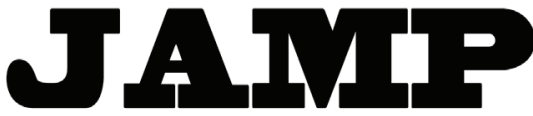

JURNAL ADMINISTRASI DAN MANAJEMEN PENDIDIKAN

\title{
HUBUNGAN GAYA KEPEMIMPINAN KEPALA SEKOLAH DAN KINERJA GURU
}

\author{
Bella Nadya Rosaliawati \\ Mustiningsih \\ Imron Arifin \\ E-mail: bellanadya15@yahoo.com \\ Universitas Negeri Malang, Jalan Semarang No.5 Malang
}

\begin{abstract}
Study aims to: reveal the headmaster's style of leadership; knowing the performance of teachers'; knowing the relationship between the principal's autocratic leadership style and teacher performance; knowing the relationship between the principal's democratic leadership style and teacher performance; knowing the relationship between the leadership style of the principal's participation and teacher performance; knowing the relationship between the principal's leadership style of free control and teacher performance; and knowing the relationship between leadership style and teacher performance. This research uses a quantitative approach and the instrument used questionnaire with the respondents teacher's. Data analysis technique used is descriptive analysis and correlation analysis techniques. Based on the results of the study can be concluded that: headmaster's style of leadership consisting of autocratic, participation, democracy and free control classified as good, with the level of frequency the leadership style used is democratic leadership style, participation, free control and autocratic; the level of performance of teachers in learning planning, learning implementation, and evaluation of learning is good; there is no significant relationship between the autocratic leadership style of school principals and teacher performance; there is a significant positive relationship between the democratic leadership style of school principals and teacher performance; there is a significant positive relationship between the leadership style of principals' participation and the performance of teachers; there is a significant positive relationship between the leadership style of the teacher's free control and the performance of teachers; and there is a significant positive relationship between the principal's leadership style and teacher performance.
\end{abstract}

Keywords : style of leadership, teacher's performance, teacher's of state high school Malang.

Abstrak : Penelitian bertujuan untuk mengungkap gaya kepemimpinan kepala sekolah; mengungkap kinerja guru; mengetahui hubungan gaya kepemimpinan otokratis kepala sekolah dan kinerja guru; mengetahui hubungan gaya kepemimpinan demokrasi kepala sekolah dan kinerja guru; mengetahui hubungan gaya kepemimpinan partisipasi kepala sekolah dan kinerja guru; mengetahui hubungan gaya kepemimpinan kendali bebas kepala sekolah dan kinerja guru; dan mengetahui hubungan gaya kepemimpinan dan kinerja guru. Penelitian menggunakan pendekatan kuantitatif dan instrumen berupa angket dengan responden guru. Teknik analisis deskriptif dan korelasi digunakan dalam penelitian ini. Berdasarkan hasil penelitian dapat disimpulkan: gaya kepemimpinan kepala sekolah yang terdiri dari otokratis, partisipasi, demokrasi dan kendali bebas tergolong baik, dengan tingkat keseringan gaya kepemimpinan yang digunakan adalah gaya kepemimpinan demokratis, partisipasi, kendali bebas dan otokratis; tingkat kinerja guru dalam perencanaan pembelajaran, pelaksanaan pembelajaran, dan evaluasi pembelajaran tergolong baik; tidak terdapat hubungan yang signifikan antara gaya kepemimpinan otokratis kepala sekolah dan kinerja guru; ada hubungan positif yang signifikan antara gaya kepemimpinan demokrasi kepala sekolah dan kinerja 


\begin{abstract}
guru; ada hubungan positif yang signifikan antara gaya kepemimpinan partisipasi kepala sekolah dan kinerja guru; ada hubungan positif yang signifikan antara gaya kepemimpinan kendali bebas kepala sekolah dan kinerja guru; dan ada hubungan positif yang signifikan antara gaya kepemimpinan kepala sekolah dan kinerja guru.
\end{abstract}

Kata kunci: gaya kepemimpinan, kinerja guru, dan guru SMA Negeri Kota Malang.

Guru dituntut memiliki kinerja yang mampu memberikan dan merealisasikan harapan dan keinginan semua pihak terutama masyarakat umum yang telah mempercayai sekolah dan guru dalam membina anak didik. Secara umum mutu 2 pendidikan yang baik menjadi tolak ukur bagi keberhasilan kinerja yang ditunjukkan guru. Sebagai tenaga pendidik, guru menjadi faktor penentu dalam peningkatan mutu pendidikan di sekolah. Oleh karena itu, para pendidik (guru) harus dapat meningkatkan kinerja dalam melaksanakan tugas karena pendidikan di masa yang akan datang menuntut keterampilan profesi pendidikan yang bermutu. Sehingga kinerja guru yang profesioanal dapat menjadi angin segar bagi keberhasilan dalam dunia pendidikan di masa yang akan datang. Masalah kinerja guru menjadi sorotan berbagai pihak yang harus mendapatkan perhatian sentral, hal ini dikarenakan figur seorang guru merupakan sorotan paling utama ketika berbicara mengenai masalah pendidikan. Peningkatan kinerja guru di sekolah menjadi salah satu tugas dari seorang kepala sekolah. Untuk itu, dalam pelaksanaan peningkatan kinerja guru dapat dilakukan dengan peran penting dari kepala sekolah melalui kepemimpinannya. Kinerja penting untuk diteliti karena ukuran keberhasilan dari suatu organisasi atau sekolah dapat dilihat dari kinerja maupun pelaksanaan pekerjaannya sehingga kemajuan suatu sekolah dapat dipengaruhi oleh kinerja guru-gurunya. Penilaian kinerja guru sebenarnya merupakan penilaian terhadap penampilan kerja guru itu sendiri terhadap taraf potensi kerja guru dalam upaya mengembangkan diri untuk kepentingan sekolah. Kepala sekolah dalam memimpin suatu organisasi diharapkan mampu menangani perrmasalahan-permasalahan yang ada. Masalah kepemimpinan selalu memberikan kesan yang menarik sebab keberhasilan suatu organisasi ditentukan oleh kualitas kepemimpinan juga.

Kepala sekolah adalah seseorang yang memiliki tugas bertanggungjawab penuh terhadap seluruh kegiatan yang ada di sekolah, maka dari itu dalam menjalankan tugasnya kepala sekolah tidak dapat melakukannya sendiri. Berdasarkan Permendikbud No 6 Tahun 2018 Tentang Penugasan Guru Sebagai Kepala Sekolah disebutkan bahwa

Kepala Sekolah adalah guru yang diberi tugas untuk memimpin dan mengelola satuan pendidikan yang meliputi taman kanak-kanak (TK), taman kanak-kanak luar biasa (TKLB), sekolah dasar (SD), sekolah dasar luar biasa (SDLB), sekolah menengah pertama (SMP), sekolah menengah pertama luar biasa (SMPLB), sekolah menengah atas (SMA), sekolah menengah kejuruan (SMK), sekolah menengah atas luar biasa (SMALB), atau Sekolah Indonesia di Luar Negeri.

Salah satu faktor yang dapat meningkatkan kinerja guru adalah kepemimpinan yang bisa dilihat melalui cara memimpin seseorang terhadap bawahannya. Senada dengan penelitian terdahulu oleh Airin (2016) yang menyatakan gaya kepemimpinan kepala sekolah memiliki hubungan yang signifikan dengan kinerja guru. Kinerja guru adalah keseluruhan perilaku guru dalam mencapai tujuan terhadap pelaksanaan tugas yang dibebankan kepadanya baik sebagai pengajar, pelatih, pembimbing, pembina, dan pendidik siswa, sehingga dari penguasaan tugas pokok tersebut dapat meningkatkan profesi guru dalam mengajar (Kempa, 2015:10). Kinerja tentu menjadi faktor yang sangat penting dalam menentukan kualitas kerja seseorang termasuk seorang guru.

Kota Malang memiliki 10 SMA Negeri yang memiliki berbagai karakteristik yang berbedabeda. Salah satunya karakteristik siswa yang bisa dipengaruhi oleh guru karena guru adalah penentu keberhasilan di sekolah. Peranan penting guru tersebut dapat dicapai melalui tugas dari kepala sekolah dalam melaksanakan kepemimpinannya.

Gaya kepemimpinan adalah teknik tertentu yang diperlukan untuk mempengaruhi, mendorong, mengarahkan, dan menggerakkan. Menurut Mustiningsih (2013) gaya kepemimpinan adalah cara seorang pemimpin bersikap, berkomunikasi, dan berinteraksi dengan orang lain dalam mempengaruhi 
orang untuk melakukan sesuatu. Indikator gaya kepemimpinan kepala sekolah, yaitu: (1) Otokratis; (2) Demokrasi; (3) Partisipasi; dan (4) Kendali bebas.

Kinerja guru dalam pembelajaran adalah derajat pencapaian prestasi yang dicapai oleh guru. Menurut Mangkunegara (2001) kinerja dapat didefinisikan sebagai hasil kerja secara kualitas dan kuantitas yang dapat dicapai oleh seorang pegawai dalam melaksanakan tugas sesuai dengan tanggung jawab yang diberikan kepadanya. Indikator penilaian kinerja guru, yaitu: (1) Perencanaan program kegiatan pembelajaran; (2) pelaksanaan kegiatan pembelajaran; dan (3) evaluasi/penilaian pembelajaran.

\section{METODE}

Penelitian ini menggunakan pendekatan kuantitatif dengan rancangan penelitian deskriptif korelasional. Pengumpulan data menggunakan instrumen atau angket. Analisis data bersifat deskriptif dan analisis statistik Analisis statistik yang digunakan dalam penelitian ini adalah teknik analisis korelasi pearson, koefiesien determinasi dan uji hipotesis. Hal ini dikarenakan, ingin mendeskripsikan dan menemukan hubungan variabel bebas terhadap variabel terikat. Dalam melakukan analisis data penelitian menggunakan bantuan Method of Successive Interval (MSI) dan Statistical Package for Social Science for windows versi 20.0. Sampel yang digunakan pada penelitian ini diambil menggunakan rumus formula Slovin. Jumlah sampel yang diambil di tiap objek penelitian menggunakan teknik Propotional Random Sample dengan cara undian. Ditemukan sampel sejumlah 239 guru dari populasi sejumlah 594 guru dengan lokasi penelitian SMA Negeri Kota Malang. Instrumen yang digunakan dalam penelitian ini berupa angket.

\section{HASIL}

\section{Deskriptif Variabel Gaya Kepemimpinan}

Berdasarkan hasil analisis didapatkan deskripsi data variabel gaya kepemimpinan yang dapat dilihat sebagai berikut.

Tabel 1 Hasil Analisis Deskriptif Variabel Gaya Kepemimpinan

\begin{tabular}{llll}
\hline No & Gaya Kepemimpinan & Mean & Kriteria \\
\hline 1 & Otokratis & 3.6 & Kadang-kadang \\
2 & Demokratis & 4.2 & Sering \\
3 & Partisipasi & 4.1 & Sering \\
4 & Kendali Bebas & 3.7 & Sering \\
\hline
\end{tabular}

Dilihat dari tabel 1 menunjukkan, bahwa kepala sekolah di SMA Negeri Kota Malang cenderung menggunakan gaya kepemimpinan demokratis dengan mean sebesar 4,2 dengan kriteria sering. Diikuti oleh gaya partisipasi dengan mean 4,1, gaya kendali bebas dengan mean 3,7 dan gaya otokratis dengan mean 3,6

\section{Deskripsi Indikator Gaya Kepemimpinan Otokratis}

Berdasarkan hasil analisis didapatkan deskripsi data indikator gaya kepemimpinan otokratis yang dapat dilihat sebagai berikut.

Tabel 2 Hasil Analisis Deskriptif Indikator Gaya Kepemimpinan Otokratis

\begin{tabular}{llcc}
\hline No & \multicolumn{1}{c}{ Kategori } & Interval & Frekuensi \\
\hline 1 & Selalu & $4,6-5,4$ & 5 \\
2 & Sering & $3,7-4,5$ & 113 \\
3 & Kadang-kadang & $2,8-3,6$ & 109 \\
4 & Jarang & $1,9-2,7$ & 12 \\
5 & Tidak Pernah & $1-1,8$ & 0 \\
& Total & & 239 \\
\hline
\end{tabular}


Dilihat dari Tabel 2 menunjukkan, bahwa tingkat gaya kepemimpinan kepala sekolah di SMA Negeri Kota Malang dilihat dari indikator otokratis tergolong kategori selalu dengan frekuensi 5. Tergolong kategori sering dengan frekuensi 113. Tergolong kategori kadang-kadang dengan frekuensi 109. Tergolong kategori jarang dengan frekuensi 12. Sementara tergolong kategori tidak pernah dengan frekuensi 0 .

\section{Deskripsi Indikator Gaya Kepemimpinan Demokratis}

Berdasarkan hasil analisis didapatkan deskripsi data indikator gaya kepemimpinan demokratis yang dapat dilihat sebagai berikut.

Tabel 3 Hasil Analisis Deskriptif Indikator Gaya Kepemimpinan Demokratis

\begin{tabular}{llcc}
\hline No & \multicolumn{1}{c}{ Kategori } & Interval & Frekuensi \\
\hline 1 & Selalu & $4,6-5,4$ & 52 \\
2 & Sering & $3,7-4,5$ & 158 \\
3 & Kadang-kadang & $2,8-3,6$ & 25 \\
4 & Jarang & $1,9-2,7$ & 4 \\
5 & Tidak Pernah & $1-1,8$ & 0 \\
& Total & & 239 \\
\hline
\end{tabular}

Dilihat dari tabel 3 menunjukkan, bahwa tingkat gaya kepemimpinan kepala sekolah di SMA Negeri Kota Malang tergolong kategori selalu dengan frekuensi 52. Tergolong kategori sering dengan frekuensi 158. Tergolong kategori kadang-kadang dengan frekuensi 25. Tergolong kategori jarang dengan frekuensi 4. Sementara tergolong kategori tidak pernah dengan frekuensi 0.

\section{Deskripsi Indikator Gaya Kepemimpinan Partisipasi}

Berdasarkan hasil analisis didapatkan deskripsi data indikator gaya kepemimpinan partisipasi yang dapat dilihat sebagai berikut.

Tabel 4 Hasil Analisis Deskriptif Indikator Gaya Kepemimpinan Partisipasi

\begin{tabular}{llcc}
\hline No & \multicolumn{1}{c}{ Kategori } & Interval & Frekuensi \\
\hline 1 & Selalu & $4,6-5,4$ & 68 \\
2 & Sering & $3,7-4,5$ & 132 \\
3 & Kadang-kadang & $2,8-3,6$ & 22 \\
4 & Jarang & $1,9-2,7$ & 17 \\
5 & Tidak Pernah & $1-1,8$ & 0 \\
& Total & & 239 \\
\hline
\end{tabular}

Dilihat dari tabel 4 menunjukan, bahwa tingkat gaya kepemimpinan kepala sekolah di SMA Negeri Kota Malang dilihat dari indikator partisipasi tergolong kategori selalu dengan frekuensi 68. Tergolong kategori sering dengan frekuensi 132. Tergolong kategori kadang-kadang dengan frekuensi 22. Tergolong kategori jarang dengan frekuensi 17. Sementara tergolong kategori tidak pernah dengan frekuensi 0 .

\section{Deskripsi Indikator Gaya Kepemimpinan Kendali Bebas}

Berdasarkan hasil analisis didapatkan deskripsi data indikator gaya kepemimpinan bendali bebas yang dapat dilihat sebagai berikut. 
Tabel 5 Hasil Analisis Deskriptif Indikator Gaya Kepemimpinan Kendali Bebas

\begin{tabular}{llcc}
\hline No & Kategori & Interval & Frekuensi \\
\hline 1 & Selalu & $4,6-5,4$ & 19 \\
2 & Sering & $3,7-4,5$ & 124 \\
3 & Kadang-kadang & $2,8-3,6$ & 71 \\
4 & Jarang & $1,9-2,7$ & 21 \\
5 & Tidak Pernah & $1-1,8$ & 4 \\
& Total & & 239 \\
\hline
\end{tabular}

Dilihat dari tabel 5 menunjukkan, bahwa tingkat gaya kepemimpinan kepala sekolah di SMA Negeri Kota Malang dilihat dari indikator kendali bebas yang berdasarkan deskripsi pemimpin cenderung membiarkan anggota, keterlibatan pemimpin sedikit, dan pengambilan keputusan didelegasikan sepenuhnya kepada bawahan tergolong kategori selalu dengan frekuensi 68. Tergolong kategori sering dengan frekuensi 132. Tergolong kategori kadang-kadang dengan frekuensi 22. Tergolong kategori jarang dengan frekuensi 17. Sementara tergolong kategori tidak pernah dengan frekuensi 0.

\section{Deskripsi Variabel Kinerja Guru}

Berdasarkan hasil analisis didapatkan deskripsi data variabel kinerja guru yang dapat dilihat sebagai berikut.

Tabel 6 Hasil Analisis Deskriptif Variabel Kinerja Guru

\begin{tabular}{llccc}
\hline No & Kategori & Interval & Frekuensi & Persentase \\
\hline 1 & Sangat baik & $78-93$ & 79 & $33.05 \%$ \\
2 & Baik & $63-77$ & 158 & $66.11 \%$ \\
3 & Cukup Baik & $48-62$ & 2 & $0.84 \%$ \\
4 & Kurang Baik & $33-47$ & 0 & $0.00 \%$ \\
5 & Tidak Baik & $18-32$ & 0 & $0.00 \%$ \\
& Total & & 239 & $100.00 \%$ \\
\hline
\end{tabular}

Dilihat pada Tabel 6 menunjukkan, bahwa kinerja guru di SMA Negeri Kota Malang tergolong sangat baik sebesar 33,05\%. Tergolong dalam kategori baik sebesar 66,11\%. Tergolong dalam kategori cukup baik 0,84\%. Tergolong dalam kategori kurang baik sebesar $0 \%$. Sementara tergolong dalam kategori tidak baiksebesar $0 \%$. Berdasarkan analisis dari data diatas dapat disimpulkan, bahwa persentase kinerja guru di SMA Negeri Kota Malang dalam kategori 'baik', yakni sebesar 66,11 \%.

\section{Deskripsi Indikator Perencanaan Pembelajaran}

Berdasarkan hasil analisis didapatkan deskripsi data indikator perencanaan pembelajaran yang dapat dilihat sebagai berikut.

Tabel 7 Hasil Analisis Deskriptif Indikator Perencanaan Pembelajaran

\begin{tabular}{llccc}
\hline No & Kategori & Interval & Frekuensi & Persentase \\
\hline 1 & Sangat baik & $26-30$ & 0 & $0.00 \%$ \\
2 & Baik & $21-25$ & 127 & $53.14 \%$ \\
3 & Cukup Baik & $16-20$ & 111 & $46.44 \%$ \\
4 & Kurang Baik & $11-15$ & 1 & $0.42 \%$ \\
5 & Tidak Baik & $6-10$ & 0 & $0.00 \%$ \\
& Total & & 239 & $100.00 \%$ \\
\hline
\end{tabular}


Dilihat pada Tabel 7 menunjukkan, bahwa tingkat kinerja guru di SMA Negeri Kota Malang dilihat dari indikator perencanaan pembelajaran tergolong sangat baik sebesar $0 \%$. Tergolong dalam kategori baik sebesar 53,14\%. Tergolong dalam kategori cukup baik 46,44\%. Tergolong dalam kategori kurang baik sebesar $0,42 \%$. Sementara tergolong dalam kategori tidak baik sebesar $0 \%$. Berdasarkan analisis data diatas dapat disimpulkan, bahwa persentase tingkat kinerja guru perencanaan pembelajaran di SMA Negeri Kota Malang tergolong dalam kategori 'baik', yakni sebesar 53,14 \%.

\section{Deskripsi Indikator Pelaksanaan Pembelajaran}

Berdasarkan hasil analisis didapatkan deskripsi data indikator pelaksanaan pembelajaran yang dapat dilihat sebagai berikut.

Tabel 8 Hasil Analisis Deskriptif Indikator Pelaksanaan Pembelajaran

\begin{tabular}{llccc}
\hline No & Kategori & Interval & Frekuensi & Persentase \\
\hline 1 & Sangat Baik & $31-36$ & 75 & $31.38 \%$ \\
2 & Baik & $25-30$ & 163 & $68.20 \%$ \\
3 & Cukup Baik & $19-24$ & 1 & $0.42 \%$ \\
4 & Kurang Baik & $13-18$ & 0 & $0.00 \%$ \\
5 & Tidak Baik & $7-12$ & 0 & $0.00 \%$ \\
& Total & & 239 & $100.00 \%$ \\
\hline
\end{tabular}

Dilihat pada tabel 8 menunjukkan, bahwa tingkat kinerja guru di SMA Negeri Kota Malang dilihat dari indikator pelaksanaan tergolong sangat baik sebesar 31,38\%. Tergolong dalam kategori baik sebesar $68,20 \%$. Tergolong dalam kategori cukup baik 0,42\%. Tergolong dalam kategori kurang baik sebesar $0 \%$. Sementara tergolong dalam kategori tidak baik sebesar $0 \%$. Berdasarkan analisis data diatas dapat disimpulkan, bahwa persentase tingkat kinerja guru pelaksanaa pembelajaran di SMA Negeri Kota Malang tergolong dalam kategori 'baik', yakni sebesar 68,20 \%.

\section{Deskripsi Indikator Evaluasi Pembelajaran}

Berdasarkan hasil analisis didapatkan deskripsi data indikator pelaksanaan pembelajaran yang dapat dilihat sebagai berikut.

\section{Tabel 9 Hasil Analisis Deskriptif Indikator Evaluasi Pembelajaran}

\begin{tabular}{llccc}
\hline No & Kategori & Interval & Frekuensi & Persentase \\
\hline 1 & Sangat Baik & $26-30$ & 76 & $31.80 \%$ \\
2 & Baik & $21-25$ & 134 & $56.07 \%$ \\
3 & Cukup Baik & $16-20$ & 25 & $10.46 \%$ \\
4 & Kurang Baik & $11-15$ & 0 & $0.00 \%$ \\
5 & Tidak Baik & $6-10$ & 4 & $1.67 \%$ \\
& Total & & 239 & $100.00 \%$ \\
\hline
\end{tabular}

Dilihat pada tabel 9 menunjukkan, bahwa tingkat kinerja guru di SMA Negeri Kota Malang dilihat dari indikator evaluasi pembelajaran tergolong sangat baik sebesar 31,80\%. Tergolong dalam kategori baik sebesar 56,07\%. Tergolong dalam kategori cukup baik 10,46\%. Tergolong dalam kategori kurang baik sebesar $0 \%$. Sementara tergolong dalam kategori tidak baik sebesar 1,67\%. Berdasarkan analisis data diatas dapat disimpulkan, bahwa persentase tingkat kinerja guru evaluasi pembelajaran di SMA Negeri Kota Malang tergolong dalam kategori ‘baik’, yakni sebesar 56,07 \%. 


\section{Hubungan Gaya Kepemimpinan dan Kinerja Guru}

Tabel 10 Pengujian Hipotesis

\begin{tabular}{|c|c|c|c|c|}
\hline No & Hipotesis & Hasil Uji & Sign & Hasil Pengujian \\
\hline 1 & $\begin{array}{l}\text { H0: tidak ada hubungan } \\
\text { gaya kepemimpinan otokratis } \\
\text { kepala sekolah } \\
\text { dan kinerja guru }\end{array}$ & 0,260 & 0,050 & H0 diterima \\
\hline 2 & $\begin{array}{l}\text { H0: tidak ada hubungan gaya } \\
\text { kepemimpinan demokrasi } \\
\text { kepala sekolah } \\
\text { dan kinerja guru }\end{array}$ & 0,000 & $\mathbf{0 , 0 5 0}$ & H0 ditolak \\
\hline 3 & $\begin{array}{l}\text { Ho: tidak ada hubungan gaya } \\
\text { kepemimpinan partisipasi } \\
\text { kepala sekolah dan kinerja } \\
\text { guru }\end{array}$ & 0,000 & 0,050 & H0 ditolak \\
\hline 4 & $\begin{array}{l}\text { H0: tidak ada hubungan gaya } \\
\text { kepemimpinan kendali bebas } \\
\text { kepala sekolah } \\
\text { dan kinerja guru }\end{array}$ & 0,000 & $\mathbf{0 , 0 5 0}$ & H0 ditolak \\
\hline 5 & $\begin{array}{l}\text { H0: tidak ada hubungan } \\
\text { gaya kepemimpinan kepala } \\
\text { sekolah } \\
\text { dan kinerja guru }\end{array}$ & 0,000 & 0,050 & H0 ditolak \\
\hline
\end{tabular}

Dilihat pada Tabel 10 nomor 1 menunjukkan, bahwa tidak terdapat hubungan antar kedua variabel yang signifikan, hal ini menunjukan tidak adanya hubungan yang signifikan antara dua variabel tersebut, artinya gaya kepemimpinan otokratis tidak berhubungan dengan kinerja guru. Pada nomor 2 menunjukkan, bahwa terdapat hubungan antar kedua variabel yang signifikan dan positif, hal ini menunjukan adanya hubungan yang signifikan antara dua variabel tersebut, artinya ada hubungan gaya kepemimpinan demokratis dan kinerja guru. Pada nomor 3 menunjukkan, bahwa terdapat hubungan antar kedua variabel yang signifikan dan positif, hal ini menunjukan adanya hubungan yang signifikan antara dua variabel tersebut, artinya ada hubungan gaya kepemimpinan partisipasi dan kinerja guru. Pada nomor 4 menunjukkan, bahwa terdapat hubungan antar kedua variabel yang signifikan dan positif, hal ini menunjukan adanya hubungan yang signifikan antara dua variabel tersebut, artinya ada hubungan gaya kepemimpinan kendali bebas dan kinerja guru. Pada nomor 5 menunjukan, bahwa terdapat hubungan antar kedua variabel yang signifikan dan positif, hal ini menunjukan adanya hubungan yang signifikan antara dua variabel tersebut, artinya ada hubungan gaya kepemimpinan dan kinerja guru.

\section{PEMBAHASAN}

\section{Gaya Kepemimpinan Kepala Sekolah di SMA Negeri Kota Malang}

Berdasarkan hasil penelitian yang dilaksanakan, diketahui bahwa tingkat gaya kepemimpinan kepala sekolah di SMA Negeri Kota Malang tergolong baik dengan persentase 61,51\% dengan cenderung menggunakan gaya kepemimpinan demokratis dengan mean sebesar 4,2 dengan kriteria sering. Hal ini menunjukkan tingkat gaya kepemimpinan kepala sekolah di SMA Negeri Kota Malang tergolong 
baik. Gaya kepemimpinan merupakan teknik yang diperlukan untuk mempengaruhi, mendorong, mengarahkan, dan menggerakkan bawahan. Sebagaimana yang dikemukakan Mustiningsih (2013: 101) mengartikan bahwa: "leadership style is the manner and approach of providing direction,implementing plans, and motivating people" (gaya kepemimpinan adalah cara dan pendekatan yang digunakan pemimpin dalam memberikan perintah, mengimplementasikan rencana dan memotivasi anggotannya). Selain itu (Mustiningsih, 2013: 102) juga berpendapat bahwa "gaya kepemimpinan pada dasarnya mengandung pengertian sebagai suatu perwujudan tingkah laku dari seorang pemimpin, yang menyangkut kemampuannya dalam memimpin. Perwujudan tersebut biasanya membentuk suatu pola atau bentuk tertentu".

Hasil pengolahan data mengenai gaya kepemimpinan otokratis di SMA Negeri Kota Malang tergolong baik. Hal ini dibuktikan dari 113 responden atau 47,28\% menyatakan bahwa beberapa deskripsi dari indikator otokratis seperti kepala sekolah menegakkan peraturan dengan tegas, adanya kontrol pemimpin yang ketat, dan memberikan hukumanterdapat pada kepala sekolah di SMA Negeri Kota Malang. Sependapat dengan Mustiningsih (2013:111) kepemimpinan ini pada umumnya negatif, yang berdasarkan atas ancaman dan hukuman. Selain itu Wardana (2014:379) juga berpendapat pemimpin otokratis yaitu pemimpin yang mengkomando, mengharap kepatuhan, dan memberikan hukuman. Hasil penelitian ini mendukung teori kepemimpinan dari Henslin (2007) yang menyatakan bahwa gaya kepemimpinan otoriter (authoritarian style) adalah seseorang yang memberikan perintah kepada karyawan laki-laki maupun perempuan dan memberitahu apa yang pasti harus mereka lakukan. Meskipun demikian menurut Mustiningsih (2013) ada juga beberapa manfaatnya antaranya memungkinkan pengambil keputusan dengan cepat serta memungkinkan pendayagunaan pegawai yang kurang kompeten. Gaya kepemimpinan jenis ini dapat digunakan Kepala Sekolah dalam memberdayakan guru yang kurang kompeten serta dapat digunakan pada saat keadaan yang membutuhkan pengambilan keputusan yang cepat.

Hasil pengolahan data mengenai gaya kepemimpinan demokratis di SMA Negeri Kota Malang tergolong baik. Hal ini dibuktikan dari 158 responden atau 66,11\% menyatakan bahwa beberapa deskripsi dari indikator demokratis seperti kepala sekolah melibatkan bawahan dalam proses pembuatan keputusan kepala sekolah memberi wewenang luas kepada bawahan, dan kontrol kepala sekolah sedang/ medium terdapat pada kepala sekolah di SMA Negeri Kota Malang. Sependapat dengan (Mustiningsih, 2013:111) kepemimpinan demokrasi cenderung bermoral tinggi dapat bekerja sama, mengutamakan mutu kerja dan dapat mengarahkan diri sendiri. Selain itu Wardana (2014:379) juga berpendapat pemimpin demokratis yaitu pemimpin yang konsultasi dengan bawahan dan mendorong keikutsertaan bawahan. Hasil penelitian ini mendukung teori kepemimpinan dari Henslin (2007) yang menyatakan bahwa gaya kepemimpinan demokratis (democratic leader) adalah seseorang yang mudah untuk berdiskusi dengan karyawannya dan membantu menggambarkan langkah-langkah yang akan membantu mereka mencapai tujuannya.

Hasil pengolahan data mengenai gaya kepemimpinan partisipasi di SMA Negeri Kota Malang tergolong baik. Hal ini dibuktikan dari 132 responden atau 55,23\% menyatakan bahwa beberapa deskripsi dari indikator partisipasi seperti kepala sekolah saling menukar ide, menerima saran bawahan dan kepala sekolah aktif mendengar terdapat pada kepala sekolah di SMA Negeri Kota Malang. Sependapat dengan Mustiningsih (2013:111) kepemimpinan parsitipasi lebih banyak mendesentralisasikan wewenang yang dimilikinya sehingga keputusan yang diambil tidak bersifat sepihak. Selain itu Wardana (2014:379) juga berpendapat pemimpin partisipasi yaitu pemimpin yang menyeimbangkan orientasi pada tugas dan orientasi pada manusia. Pemimpin dengan gaya partisipatif akan mendorong kemampuan bawahan mengambil keputusan. Dengan demikian, pimpinan akan selalu membina bawahan untuk menerima tanggung jawab yang lebih besar (Mustiningsih, 2013).

Hasil pengolahan data mengenai gaya kepemimpinan kendali bebas di SMA Negeri Kota Malang tergolong baik. Hal ini dibuktikan dari 124 responden atau 51,88\% menyatakan bahwa beberapa deskripsi dari indikator kendali bebas seperti kepala sekolah cenderung membiarkan anggota, keterlibatan kepala sekolah sedikit, dan pengambilan keputusan didelegasikan sepenuhnya kepada bawahan terdapat pada kepala sekolah di SMA Negeri Kota Malang. Sependapat dengan Mustiningsih (2013:111) 
kepemimpinan kendali bebas memberikan kekuasaan penuh terhadap bawahan, struktur organisasi bersifat longgar dan pemimpin bersifat pasif atau pemimpin menghindari kuasa dan tanggungjawab, kemudian menggantungkannya kepada kelompok baik dalam menetapkan tujuan dan menanggulangi masalahnya sendiri. Selain itu Wardana (2014:379) juga berpendapat pemimpin bebas kendali yaitu pemimpin yang memberikan kesempatan penuh pada bawahan. Hasil penelitian ini mendukung teori kepemimpinan dari Henslin (2007) yang menyatakan bahwa gaya kepemimpinan kendali bebas/laissezfaire (laissezfaire leader) adalah seorang pemimpin yang mempunyai sifat terbuka terhadap bawahannya, dan memberikan kepercayaan penuh terhadap bawahannya untuk mengambil keputusan namun masih dalam peraturan yang berlaku dalam perusahaan.

\section{Kinerja Guru}

Berdasarkan hasil penelitian yang dilaksanakan, diketahui bahwa tingkat kinerja guru di SMA Negeri Kota Malang tergolong baik. Hal ini dibuktikan dari 158 responden atau sebesar $66,11 \%$. Hal ini menunjukan bahwa kinerja guru di SMA Negeri Kota Malang dalam kategori baik. Kinerja guru yang baik dapat menghasilkan pembelajaran yang berkualitas.

Tingkat kinerja guru di SMA Negeri Kota Malang yang tergolong baik, menunjukkan bahwa guru di SMA Negeri Kota Malang memiliki kinerja yang baik. Kinerja guru adalah derajat pencapaian prestasi yang dicapai oleh guru yang dilihat melalui kegiatan perencanaan pembelajaran, pelaksanaan pembelajaran, pelaksanaan penilaian pembelajaran, dan tindak lanjut hasil penilaian. Sebagaimana yang dikemukakan Mangkunegara (2001: 32) kinerja dapat didefinisikan sebagai hasil kerja secara kualitas dan kuantitas yang dapat dicapai oleh seorang pegawai dalam melaksanakan tugas sesuai dengan tanggung jawab yang diberikan kepadanya. Selain itu Wibowo (2011:87) mengatakan bahwa "kinerja guru dipengaruhi oleh pengetahuan, kemampuan, sikap, gaya kerja, kepribadian, minat, dasar-dasar nilai, kepercayaan dan gaya kepemimpinan". Menurut pendapat lain Comnes (2015:12) mengidentifikasikan "kinerja guru dapat dilihat dari tugas mengajar guru yang dibagi menjadi tiga tahap, yaitu tahap sebelum mengajar (preactive), tahap pengajaran (interactive), dan tahap sesudah pengajaran (pastactive)".

\section{Hubungan Gaya Kepemimpinan Otokratis dan Kinerja Guru di SMA Negeri Kota Malang}

Hasil penelitian menunjukkan, bahwa tidak terdapat hubungan yang signifikan antara gaya kepemimpinan kepala sekolah dan kinerja guru di SMANegeri Kota Malang. Artinya gaya kepemimpinan otokratis kepala sekolah tidak terdapat hubungan yang signifikan dengan kinerja guru di SMA Negeri Kota Malang. Hasil ini sesuai dengan penelitian sebelumnya yang dilakukan oleh Tumbol, Tewal, dan Sepang (2014) yang menyatakan tidak ada hubungan antara gaya kepemimpinan otokratis dengan prestasi kerja atau kinerja pegawai.

Hasil penelitian ini mendukung teori kepemimpinan dari Henslin (2007) yang menyatakan bahwa gaya kepemimpinan otoriter (authoritarian style) adalah seseorang yang memberikan perintah kepada karyawan laki-laki maupun perempuan dan memberitahu apa yang pasti harus mereka lakukan.

\section{Hubungan Gaya Kepemimpinan Demokratis dan Kinerja Guru di SMA Negeri Kota Malang}

Hasil penelitian menunjukkan, bahwa terdapat hubungan positif yang signifikan antara gaya kepemimpinan kepala sekolah dan kinerja guru di SMANegeri Kota Malang. Artinya gaya kepemimpinan demokrasi kepala sekolah terdapat hubungan yang signifikan dengan kinerja guru di SMA Negeri Kota Malang. Hasil ini sesuai dengan penelitian sebelumnya yang dilakukan oleh Tumbol, Tewal, dan Sepang (2014) yang menyatakan ada hubungan antara gaya kepemimpinan demokrasi dengan prestasi kerja atau kinerja pegawai.

Hasil penelitian ini mendukung teori kepemimpinan dari Henslin (2007) yang menyatakan bahwa gaya kepemimpinan demokratis (democratic leader) adalah seseorang yang mudah untuk berdiskusi dengan karyawannya dan membantu menggambarkan langkah-langkah yang akan membantu mereka mencapai tujuannya. 


\section{Hubungan Gaya Kepemimpinan Partisipasi dan Kinerja Guru di SMA Negeri Kota Malang}

Hasil penelitian menunjukkan, bahwa terdapat hubungan positif yang signifikan antara gaya kepemimpinan kepala sekolah dan kinerja guru di SMANegeri Kota Malang. Artinya gaya kepemimpinan partisipasi kepala sekolah terdapat hubungan yang signifikan dengan kinerja guru di SMA Negeri Kota Malang. Hasil ini sesuai dengan penelitian sebelumnya yang dilakukan oleh Pawikan (2011) terdapat hubungan yang positif dan signifikan antara gaya kepemimpinan partisipatif kepala sekolah dengan kinerja guru.

Hasil penelitian mendukung teori kepemimpinan dari Hasibuan (2016:172) yang menyatakan kepemimpinan Partisipatif adalah apabila dalam kepemimpinannya dilakukan dengan cara persuasif, menciptakan kerja sama yang serasi, menumbuhkan loyalitas, dan partisipasi para bawahan. Pemimpin memotivasi bawahan agar merasa ikut memiliki perusahaan. Bawahan harus berpartisipasi memberikan saran, ide, dan pertimbangan dalam proses pengambilan keputusan. Pemimpin dengan gaya partisipatif akan mendorong kemampuan bawahan mengambil keputusan. Dengan demikian, pimpinan akan selalu membina bawahan untuk menerima tanggung jawab yang lebih besar

\section{Hubungan Gaya Kepemimpinan Kendali Bebas dan Kinerja Guru di SMA Negeri Kota Malang}

Hasil penelitian menunjukkan, bahwa terdapat hubungan positif yang signifikan antara gaya kepemimpinan kepala sekolah dan kinerja guru di SMANegeri Kota Malang. Artinya gaya kepemimpinan kendali bebas kepala sekolah terdapat hubungan yang signifikan dengan kinerja guru di SMA Negeri Kota Malang. Hasil ini sesuai dengan penelitian sebelumnya yang dilakukan oleh Rahmawi (2015) bahwa gaya kepemimpinan laisez-faire atau kendali bebas berpengaruh signifikan terhadap kinerja karyawan.

Hasil penelitian ini mendukung teori kepemimpinan dari Henslin (2007) yang menyatakan bahwa gaya kepemimpinan laissez-faire (laissezfaire leader) adalah seorang pemimpin yang mempunyai sifat terbuka terhadap bawahannya, dan memberikan kepercayaan penuh terhadap bawahannya untuk mengambil keputusan namun masih dalam peraturan yang berlaku dalam perusahaan.

\section{Hubungan Gaya Kepemimpinan dan Kinerja Guru di SMA Negeri Kota Malang}

Hasil penelitian menunjukkan, bahwa terdapat hubungan positif yang signifikan antara gaya kepemimpinan kepala sekolah dan kinerja guru di SMANegeri Kota Malang. Artinya gaya kepemimpinan kepala sekolah memberikan pengaruh terhadap kinerja guru di SMA Negeri Kota Malang. Hasil ini sesuai dengan penelitian sebelumnya yang dilakukan oleh Airin (2016) dalam penelitiannya terhadap kinerja guru di SMPN Kecamatan Palembayan Kabupaten Agam menunjukkan bahwa koefisien korelasi antara gaya kepemimpinan kepala sekolah dan kinerja guru adalah signifikan. Hasil penelitian ini mendukung teori kepemimpinan Wibowo (2011: 87) yang mengatakan bahwa "kinerja guru dipengaruhi oleh gaya kepemimpinan" dan hal serupa juga dijelaskan oleh Mulyasa (2005: 115) keberhasilan kepala sekolah sebagai supervisor ditunjukkan oleh meningkatnya kesadaran pendidik (guru) untuk meningkatkan kinerja dan meningkatkan ketrampilan pendidiak (guru) dalam melaksanakan tugasnya. Hal ini dapat dikatakan pula semakin baik kepemimpinan kepala sekolah semakin meningkat pula kinerja guru.

\section{KESIMPULAN DAN SARAN}

\section{Kesimpulan}

Berdasarkan hasil penelitian dapat disimpulkan bahwa: (1) Gaya kepemimpinan kepala sekolah di SMA Negeri Kota Malang yang terdiri dari otokratis, partisipasi, demokrasi dan kendali bebas tergolong baik, dengan tingkat keseringan gaya kepemimpinan yang digunakan adalah gaya kepemimpinan demokratis, partisipasi, kendali bebas lalu otokratis; (2) tingkat kinerja guru di SMA Negeri Kota Malang dalam perencanaan pembelajaran, pelaksanaan pembelajaran, dan evaluasi pembelajaran 
tergolong baik; (3) tidak terdapat hubungan yang signifikan antara gaya kepemimpinan otokratis kepala sekolah dan kinerja guru di SMA Negeri Kota Malang; (4) ada hubungan positif yang signifikan antara gaya kepemimpinan demokrasi kepala sekolah dan kinerja guru di SMA Negeri Kota Malang; (5) ada hubungan positif yang signifikan antara gaya kepemimpinan partisipasi kepala sekolah dan kinerja guru di SMA Negeri Kota Malang; (6) ada hubungan positif yang signifikan antara gaya kepemimpinan kendali bebas kepala sekolah dan kinerja guru di SMA Negeri Kota Malang; dan (7) ada hubungan positif yang signifikan antara gaya kepemimpinan kepala sekolah dengan kinerja guru di SMA Negeri Kota Malang.

\section{Saran}

Saran yang dikemukakan dalam penelitian ini yaitu: (1) Kepada Kepala Dinas Pendidikan Kota Malang, hendaknya mendorong kepala sekolah agar kepala sekolah bisa mempertahankan serta meningkatkan kepemimpinanya dan kinerja bawahannya; (2) Kepada Kepala SMA Negeri Kota Malang, hendaknya mengadakan evaluasi dengan guru untuk saling mempertahankan kinerja demi tercapainya tujuan bersama; (3) Kepada Jurusan Administrasi Pendidikan, hasil penelitian dapat dijadikan sebagai tambahan bahan pustaka serta melengkapi informasi dalam pengembangan ilmu pengetahuan; dan (4) Kepada Peneliti Lain, hasil penelitian ini dapat dijadikan sebagai sumber referensi bagi peneliti yang akan melakukan penelitian selanjutnya dengan tema yang sama dan bisa dijadikan reverensi untuk mengungkap aspek gaya kepemimpinan yang lain.

\section{DAFTAR RUJUKAN}

Hasibuan, M. S.P. 2016. Manajemen Sumber Daya Manusia. Jakarta: PT Bumi Aksara.

Henslin, James M. 2007. Sosiologi dengan Pendekatan Membumi. Erlangga Jakarta

Kempa, R. 2015. Kepemimpinan Kepala Sekolah: studi tentang hubungan perilaku kepemimpinan, keterampilan manajerial, manajemen konflik, daya tahan stres kerja dengan kinerja guru. Yogyakarta: Ombak

Mangkunegara, A.A.A.P. 2001. Manajemen Sumber Daya Manusia Perusahaan. Bandung: Remaja Rosdakarya.

Mustiningsih. 2013. Pengantar Kepemimpinan Pendidikan. Malang: Fakultas Ilmu Pendidikan Universitas Negeri Malang.

Pawikan, A.S.R. 2011. Pengaruh gaya kepemimpinan partisipatif kepala sekolah terhadap kinerja guru sekolah menengah pertama se kecamatan nanggulan kabupaten kulon progo. Skripi tidak diterbitkan. Yogyakarta: Universitas Negeri Yogyakarta.

Peraturan Menteri Pendidikan dan Kebudayaan No 6 Tahun 2018 Tentang Penugasan Guru Sebagai Kepala Sekolah. Berita Negara Republik Indonesia Tahun 2018 Nomor 486. (Online),(https://jdih.kemdikbud.go.id), diakses 20 November 2019.

Rahmawi, S. 2015. Pengaruh Gaya Kepemimpinan Terhadap Kinerja Karyawan Pada Kantor Pusat PT. Pelabuhan Indonesia III (PERSERO) Surabaya, (Online), (https://jimfeb.ub.ac.id/index.php/jimfeb/article/view/3061), diakses 10 juli 2019.

Rochmah, A. M. Hubungan Kepemimpinan Kepala Sekolah dengan Kinerja Guru di SMPN Kecamatan Palembayan Kabupaten Agam. Skripsi tidak diterbitkan. Malang: Universitas Negeri Malang.

Tumbol, C.L., Tewal, B., \& Sepang, J,L. 2014. Gaya Kepemimpinan Otokratis, Demokratik, dan Laissez-Faire Terhadap Peningkatan Prestasi Kerja Karyawan Pada KPP Pratama Manado. Jurnal EMBA. 2 (1) : 38-47.

Wibowo. 2011. Manajemen Kinerja. Jakarta: Rajawali Pers. 